\title{
Erratum: Correcting the Name of the Spiritual Well-Being Scale as the Three-Factor Spiritual Well-Being Scale
}

\author{
Selami Kardaș ${ }^{1}$ [ \\ Muş Alparslan University
}

Because Paloutzian and Ellison (1982) had already developed a scale named the Spiritual Well-Being Scale, it is necessary to change the name of the scale independently developed by Ekşi and Kardaş (2017) to the Three-Factor Spiritual Well-Being Scale. This change helps scholars avoid any conceptual vagueness or confusion between these two measures, and helps researchers to better identify, understand, and use the specific scale most appropriate for assessing the exact concept they wish to study.

\section{Erratum: Spiritüel İyi Oluş Ölçeği'nin Adının Üç-Faktörlü Spiritüel İyi Oluş Ölçeği Olarak Düzeltilmesi Hakkında}

Paloutzian ve Ellison (1982) tarafından hâlihazırda Spiritüel İyi Oluş Ölçeği adı verilen bir ölçek geliştirildiğinden, Ekşi ve Kardaş (2017) tarafından bağımsız olarak geliştirilen ölçeğin adının "Üç-Faktörlü Spiritüel İyi Oluş Ölçeği” olarak değiştirme gerekliliği ortaya çıkmıştır. Bu değişikliğin, araştırmacıların bu iki ölçek arasındaki herhangi bir kavramsal belirsizlik veya karışıklık yaşamalarını önlemeye; ve çalışmak istedikleri kavramı değerlendirmek için en uygun spesifik ölçeği daha iyi tanımlamalarına, anlamalarına ve kullanmalarına yardımcı olacağı düşünülmektedir.

\section{References/Kaynakça}

Ekşi, H., \& Kardaş, S. (2017). Spiritual well-being: Scale development and validation. Spiritual Psychology and Counseling, 2, 73-88. http://dx.doi.org/10.12738/spc.2017.1.0022

Paloutzian, R. F., \& Ellison, C. W. (1982). Loneliness, spiritual well-being and the quality of life. In Peplau, L. A. \& Perlman, D. (Eds), Loneliness: a sourcebook of current theory, research and therapy, (pp. 224-237). New York: Wiley-Interscience.

\footnotetext{
1 Corresponding author of the concerned Article./Ilgili makalenin sorumlu yazarı. Department of Educational Sciences, Guidance and Psycholological Counseling, Muş Alparslan University, Muş Turkey. Email: selamikardas@gmail.com Citation: Kardaş, S. (2019). Erratum: Correcting the name of the Spiritual Well-Being Scale as the Three-Factor Spiritual Well-Being Scale. Spiritual Psychology and Counseling 4, 85-85. http://dx.doi.org/10.12738/spc.2019.4.1.0068
} 
